\title{
The Old Order Changeth . . .
}

". . y yielding place to new, and TOS fulfills itself in many ways." This modified quote from Tennyson"s "Idylls of the King" seems particularly appropriate for this issue.

For one thing, editor Larry Atkinson will be retiring effective December 1997. We are urgently in need of a new editor, and mention this on the off-chance that someone out there has always dreamed of assuming the mantle of editorial authority. Don't be shy, speak right up.

But there are other changes in the magazine, changes which may be evident to the careful reader. A natural evolution appears to be taking place here in the nature of articles we are receiving and consequently the nature of the magazine itself.

A brief recap: Oceanography was originally conceived as a collection of highly readable review articles which would explain exciting new directions of various subdisciplines in terms that readers from other specialties could understand. That promise was fulfilled for the first six years so as an apparent pent-up demand was fulfilled. During that time there were also some specialized research articles of the type found in professional journals. Certain issues of the magazine were devoted to a single topic, such as Modeling and Prediction (Vol. 5. No. 1) and Technology Transfer (Vol. 6, No. 3 ). New columns were introduced-The Future of Oceanography, The Oceanographer's Toolkit, book reviews. The ratio of general-review to specialized articles gradually became smaller, but the general nature of the magazine was the same.

And then, in 1995, a distinct change occurred. Since then we have received almost no review articles, and not very many of the professional-journal type either. Instead, we are seeing an increase in what some might call grey literature-workshop reports, policy pieces, reports from national or international committees, and things that read suspiciously like planning documents for large programs. This issue represents a culmination of that trend: almost every article falls into the "report" category. Although the next year will feature a series of technical review articles it is clear we are not returning to the content we began with.

Now, this is not a bad thing. In fact. one could argue that it is a very good thing. Workshops and committee activities play a large role in determining the directions that science takes, and they are normally invisible to the general community. One might say that Oceanography is providing a badly needed service by giving these articles a much wider dissemination than they would otherwise have. But it does represent a definite sea-change, "into something rich and strange" (Shakespeare. The Tempest).

- Connie Sancetta

\section{ERRATA}

The author wishes to note two corrections in his paper "Biodiversity is Biogeography: Implications for Conservation" (Oceanography Vol. 9. No. 1: 1996). He has been informed by Dr. Michael Vecchione of the National Marine Fisheries Service, National Museum of Natural History, Washington, D.C. that the octopus in Fig. 6 is not Octopus, but probably Pareledona, very likely $P$. charcoti. In addition, the quotation attributed to Angel (1991) is actually from M. Angel (1994) Nature, Vol. 367, p. 126-7 G. Carleton Ray. 25 July 1996.

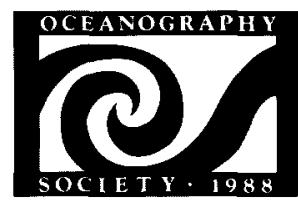

THE OCEANOGRAPHY SOCIETY

4052 Timber Ridge Drive

Virginia Beach, VA 23455 USA

(804) 464-0131; fax: (804) 464-1759

OFFICERS

Margaret Leinen, President Robert A. Duce, President-Elect Melbourne G. Briscoe, Secretary David Evans, Treasurer

Arnold L. Gordon, Past-President

COUNSELORS

Richard T. Barber

Stephen E. Calvert

Tommy D. Dickey

Robert F. Anderson Rick Spinrad

EXECUTIVE DIRECTOR Judi Rhodes

CORPORATE/INSTITUTIONAL SPONSORS Aanderaa Instruments, Inc., Woburn, MA, USA Chishitsu Chosa-Jo, Ibaraki, Japan GE Astro Space Division Princeton. NJ, USA John G. Shedd Aquarium, Chicago, IL, USA Monterey Bay Aquarium Research Institute, Pacific Grove, CA, USA

National Marine Fisheries Service, Silver Spring, MD, USA

Ober, Kaler, Grimes \& Shriver, Washington, DC, USA

RD Instruments, San Diego, CA, USA

Scripps Institution of Oceanography, La Jolla, CA, USA

Woods Hole Oceanographic Institution, Woods Hole, MA, USA

\section{OCEANOGRAPHY}

CO-EDITORS

Larry P. Atkinson

Center for Coastal Physical Oceanography

Old Dominion University

Crittenton Hall

Norfolk, VA 23529

(804) 683-5558

Internet: atkinson@ ccpo.odu.edu

Connie Sancetta

National Science Foundation

Ocean Sciences Division Room 725

4201 Wilson Blvd

Arlington, VA 22230

(703) 306-1586

Internet: csancett@nsf.gov

ASSOCIATE EDITORS

James W. Ammerman

Department of Oceanography

Texas A\&M University

College Station, TX 77843 USA

(409) $845-5105$

Gregg J. Brunskill

Australian Institute of Marine Science

PMB No. 3. Townsville, M.C

Queensland 4810, Australia

(077) 789 211; FAX (077) 725852 ;

Internet: g brunskill@aims.gov.au 